\title{
EFEK MEDIASI FINANCIAL PERFORMANCE: INTELLECTUAL CAPITAL, GROWTH OPPORTUNITY, DAN FIRM VALUE
}

\author{
Ade Ponirah \\ Manajemen Keuangan Syariah, Sekolah Tinggi Ilmu Ekonomi Syariah NU Garut \\ adeponirah@gmail.com \\ Amal Kamaludin \\ Manajemen Keuangan Syariah, Sekolah Tinggi Ilmu Ekonomi Syariah NU Garut \\ amalkamaludin211@gmail.com \\ Aqmari Zhafarina Kamal \\ Perbankan Syariah, Sekolah Tinggi Ekonomi Islam Bandung Barat \\ aqmarizhafarina2506@gmail.com
}

\begin{abstract}
Abstrak
Peningkatan kualitas kerja perusahaan akan memberikan dampak pada kemajuan perusahaan. Untuk itu perusahaan dituntut mengelola kinerja perusahaan serta modalnya dengan baik. Artikel ini bertujuan untuk mengkaji efek mediasi Financial Performance: Intellectual Capital, Growth Opportunity, Dan Firm Value. Intellectual capital merupakan tolak ukur total saham berdasarkan kolektif ilmu pengetahuan. Growth opportunity menunjukkan prediksi kemampuan perusahaan menempati posisi ekonomi pada industri sejenis. Data yang digunakan ialah data sekunder berasal dari laporan keuangan juga didukung dengan penelitian kepustakaan dan dokumentasi lalu diolah dengan cara statistik. Berdasarkan hasil penelitian pada pengujian pertama intellectual capital tidak berpengaruh terhadap firm value. Namun growth opportunity dapat memberikan pengaruh signifikan terhadap firm value. Hasil uji sobel financial performance tidak dapat memediasi pengaruh intellectual capital dan growth opprtunity terhadap firm value.
\end{abstract}

Kata Kunci: Intellectual Capital, Growth Opportunity, Financial Performance dan Firm Value

\begin{abstract}
Improving the quality of the company's work will have an impact on the progress of the company. For this reason, the company is required to manage the company's performance and capital well. This article aims to examine the mediating effects of Financial Performance: Intellectual Capital, Growth Opportunity, and Firm Value. Intellectual capital is a benchmark of total shares based on collective science. Growth opportunity shows the prediction of a company's ability to occupy economic positions in similar industries. This article uses descriptor methods and quantitative approaches, namely to describe the results of research whose data is presented in numerical form. The data in this article is secondary data taken from financial statements and supported by literature studies and documentation, which are processed statistically and quantitatively. The data in this article is secondary data taken from financial statements and supported by literature studies and documentation, which are processed statistically and quantitatively. Based on the results of research on the first test of intellectual capital has no effect on firm value. But growth opportunity can have a significant influence on firm value. The results of the sobel financial performance test cannot mediate the influence of intellectual capital and growth opprtunity on firm value.
\end{abstract}

Keywords: Intellectual Capital, Growth Opportunity, Financial Performance dan Firm Value 


\section{Pendahuluan}

Keberadaan Masyarakat Ekonomi ASEAN (MEA) memberikan banyak perubahan dalam perkembangan ekonomi di Indonesia. Fenomena ini mendorong pelaku bisnis mampu bersaing dengan pelaku bisnis mancanegara. Hal ini menyebabkan tuntutan akan peningkatan kualitas diri sebagai sumber daya manusia penggerak perusahaan harus di tingkatkan. Karena pada sejatinya keberhasilan suatu perusahaan bergantung pada tindakan, pola pikir, dan strategi yang di rencanakan oleh Sumber Daya Manusia (SDM) sebuah perusahaan. Manajemen perusahaan mulai menyadari modal untuk dapat bersaing tidak hanya mengendalkan aktiva berwujud saja, tetapi aset tak berwujud seperti inovasi, sistem informasi, manajemen organisasi dan sumber daya manusianya memainkan peran penting.

Peningkatan kualitas kerja perusahaan akan memberikan dampak pada kemajuan perusahaan. Untuk mampu bersaing dalam sengitnya jaman globalisasi ini perusahaan di tuntut untuk mengelola kinerja perusahaan serta modalnya dengan baik karena hal ini akan berdampak positif terhadap nilai perusahaan (Astari \& Suryanawa, 2017). Hal ini memberikan dampak cukup signifikan, mengubah paradigma faktor penentu keberhasilan perusahaan ada pada tenaga kerja (labour-based business) menjadi knowledge business merupakan faktor penentu keberhasilan suatu perusahaan. Dengan demikian, pengetahuan ini menjadi elemen utama dari struktur perusahaan. Kini perusahaan sangat memperhatikan SDM yang berkualitas dan memiliki ilmu pengetahuan yang tinggi. Karena jika perusahaan memiliki SDM yang berkualitas memungkinkan dapat bersaing dengan perusahaan modern lainnya (Chen et al., 2005).

Terdapat beberapa aspek penting yang perlu di sajikan dalam laporan keuangan secara gamblang yaitu terkait dengan sumber daya manusia, inovasi pelanggan atau teknologi, karena tidak dapat diidentifikasi, dikenali, dan diukur (Andriana, 2014). Hal ini menjadi sebuah tantangan untuk mengidentifiaksi, mengukur, dan mengungkapkannya dalam laporan keuangan. Salah satu alat ukur yang kerap kali digunakan yaitu Intellectual Capital (IC) (Sunarsih \& Rendra, 2012). Menurut Stewart intellectual capital merupakan ukuran modal total berdasarkan pengetahuan kolektif, informasi, teknologi, intelektual, pengalaman, pembelajaran organisasi, kompensasi, sistem kerja tim, hubungan pelanggan, dan merek yang mampu menciptakan nilai bagi suatu organisasi (Stewart, 1997).

Berdasarkan fakta bahwa IAS 38 Intangible Assets melarang pengenalan merek internal seperti publikasi alamat dan daftar pelanggan (Marcelia \& Purnomo, 2016). Kini IC berada pada posisi yang sangat strategis, menjadi tolak ukur sebagai peningkatan nilai pada beberapa perusahaan. Hal ini menjadi landasan bahwa penopang perusahaan agar dapat bertumbuh dengan pesat yaitu dengan meningkatkan IC (Juwita \& Angela, 2016). Secara keseluruhan perusahaan yang berada di Indonesia menggunakan sistem akuntansi tradisional yaitu dengan tangible asset. Namun kelemahannya sistem ini tidak menyajikan informasi mengenai aktiva tak berwujud pada suatu perusahaan (Hong et al., 2007).

Dalam meningkatkan firm value perusahaan harus dapat meminimalkan pajak dengan memberdayakan penggunaan utang, dibanding dengan perusahaan yang tidak menggunakan utang akan berdampak pada pembengkakan pajak (Wijaya et al., 2020). Namun tidak selamanya perusahaan mengandalkan hutang agar profitabilitas tidak terkuras karena pembayaran pajak (Harahap, 2019). Dengan demikian, perusahaan harus memiliki potensi pertumbuhan yang tinggi dan kecenderungan untuk menggunakan 
saham untuk kegiatan operasi perusahaan sebagai beban investasi sebagai ekuitas (Jayanti \& Binastuti, 2017). Jika peluang pertumbuhannya rendah maka perusahaan akan menggunakan hutang jangka panjangnya (Burhanuddin \& Yusuf, 2019).

Growth opportunity menunjukkan prediksi kemampuan perusahaan untuk dapat menempati posisi ekonomi secara keseluruhan pada industri sejenis (Wijayani, 2017). Perusahaan yang tumbuh dengan pesat akan mampu bersaing memperoleh hasil yang positif, dan penjualan yang terus tumbuh dengan meningkatnya pasar saham adalah contoh disertai dengan peningkatan pasar saham kemampuan perusahaan untuk mengembangkan bisnisnya dengan memperluas kemampuan internalnya (Listihayana \& Astuti, 2020). Growth opportunity tercermin dari pertumbuhan total aset, dimana total aset selama satu tahun terakhir mencerminkan profitabilitas tahun berikutnya (Taswan, 2003).

Pada penelitian ini, penulis menggunakan variabel mediasi yaitu financial performance menjadi hal yang sangat penting dalam rangka peningkatan firm value. Financial performance menitik beratkan pada variabel-variabel yang ada pada laporan keuangan. Financial performance adalah analisis yang dilakukan untuk melihat seberapa benar dan tepat perusahaan telah menerapkannya dengan menggunakan aturan eksekusi keuangan (Fahmi, 2012). Menurut teori pemangku kepentingan, pertimbangan posisi pemangku kepentingan yang paling berpengaruh dalam strategi. Saat mengungkapkan informasi keuangan, perusahaan memperhatikan pemangku kepentingan terlebih dahulu (Herawati, 2017).

Penelitian ini mengangkat tema perusahaan yang bergerak di bidang perdagangan dan distribusi bahan bakar minyak berat dan bahan kimia kasar. Alasan penulis menggunakan penelitian ini karena perusahaan ini merupakan salah satu perusahaan swasta terbesar di Indonesia yang mendistribusikan dan menjual bahan bakar dan bahan kimia dasar.

Berdasarkan teori yang telah dipaparkan dapat diasumsikan intellectual capital dan frowth opportunity dapat memberikan pengaruh terhadap firm value dengan melalui financial performance sebagai variabel mediasi. Berikut data penelitian disajikan dari perusahaan pertambangan batu bara yang terdaftar di Bursa Efek Indonesia periode 2011-2020.

Tabel 1 Data Penelitian

\begin{tabular}{|c|c|c|c|c|}
\hline Periode & $\begin{array}{c}\text { Intelectual } \\
\text { Capital }\end{array}$ & $\begin{array}{c}\text { Gowth } \\
\text { Opprtunity }\end{array}$ & $\begin{array}{c}\text { Financial } \\
\text { Performance }\end{array}$ & $\begin{array}{c}\text { Firm } \\
\text { Value }\end{array}$ \\
\hline 2011 & 89.26 & 5.00 & 7.40 & 15.4 \\
\hline 2012 & 575.55 & 24.60 & 5.50 & 33.39 \\
\hline 2013 & 467.99 & 26.10 & 4.40 & 28.04 \\
\hline 2014 & 407.57 & 19.60 & 5.50 & 28.89 \\
\hline 2015 & 296.18 & 27.30 & 6.80 & 25.45 \\
\hline 2016 & 213.58 & 25.60 & 6.40 & 36.34 \\
\hline 2017 & 208.54 & 21.80 & 7.10 & 29.62 \\
\hline 2018 & 275.25 & 11.50 & 8.20 & 25.18 \\
\hline 2019 & 259.56 & 23.90 & 3.40 & 20.94 \\
\hline 2020 & 203.57 & 11.60 & 5.00 & 12.59 \\
\hline
\end{tabular}

Sumber: www.idx.co.id 
Mengacu pada tabel di atas terdapat data yang berfluktuatif, diawali data pertama yaitu pada tahun 2011 intellectual capital sebesar 89,26 \% growth opportunity sebesar $5 \%$ financial performance sebesar 7,40\% dan firm value sebesar 15,4\%. Lalu pada periode berikutnya sampai dengan tahun 2014 hanya financial performace saja yang mengalami penurunan menjadi 5,50\%. Menginjak tahun 2015 intelectual capital dan firm value mengalami penurunan masing-masing menjadi 296,18\% dan 25,45\%. Pada tahun 2017 hampir seluruh variabel mengalami penurunan hanya financial performance saja yang terus meningkat menjadi 7,10\%. Berbeda halnya dengan tahun 2018 terdapat dua variabel yang menurun yaitu growth opportunity dan firm value sedangkan intellectual capital dan financial performance terus meningkat. Menginjak tahun 2019 hingga tahun 2020 seluruh variabel mengalami penurunan.

Mengacu pada latar belakang yang telah dipaparkan dapat digambarkan kerangka pemikiran berikut ini:

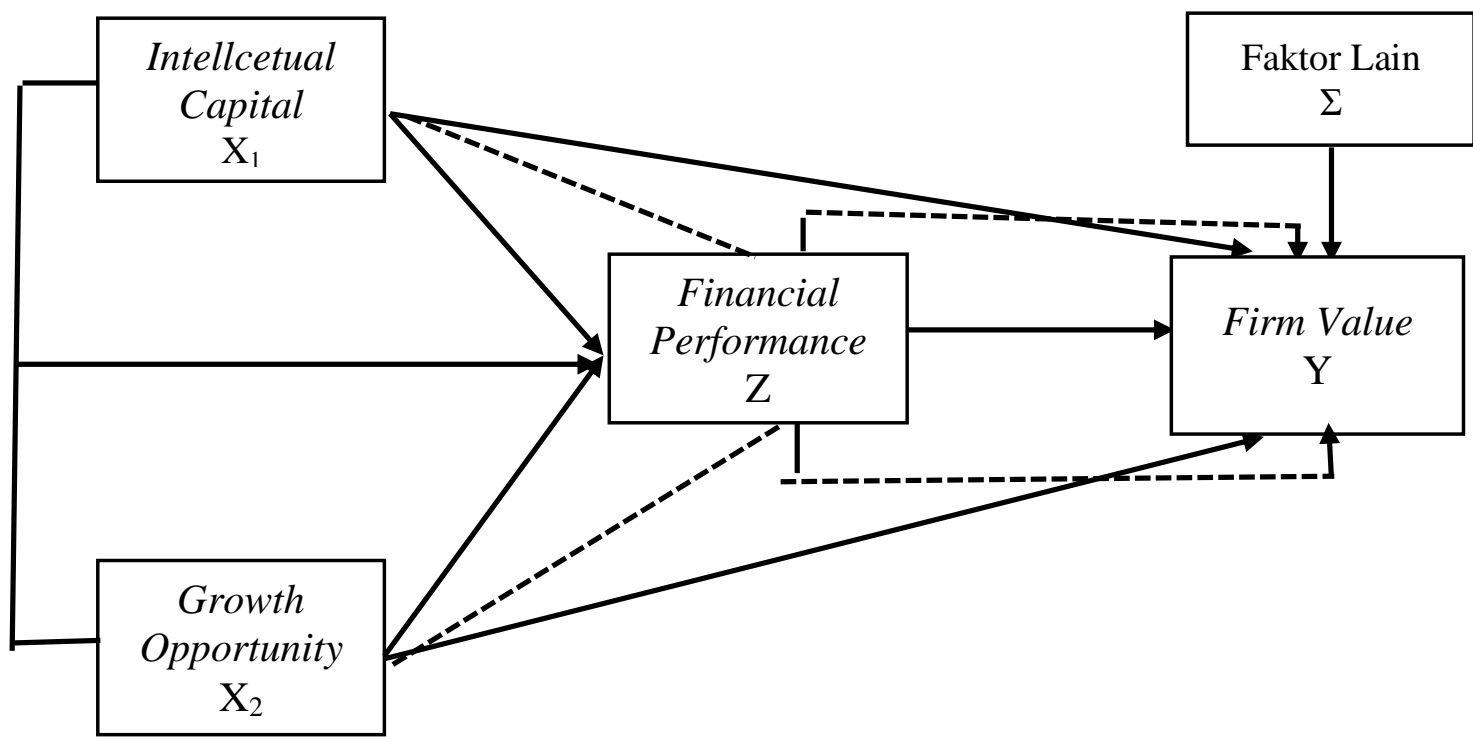

\section{Gambar 1 Kerangka Berpikir}

Berdasarkan uraian masalah di atas dan kerangka berpikir yang telah dibentuk, maka peneliti memberikan hipotesis untuk penelitian ini yaitu:

H1: Intellectual capital secara parsial berpengaruh terhadap firm value

H2: Growth Opportunity secara parsial berpengaruh terhadap firm value

H3: Intellectual Capital secara parsial berpengaruh terhadap financial performance

H4: Growth opportunity secara parsial berpengaruh terhadap financial performance

H5: Intellectual capital dan Growth opportunity secara simultan berpengaruh terhadap firm value melalui financial performance sebagai variabel mediasi

\section{Metode}

Penelitian ini menggunakan pendekatan deskriptif melalui pendekatan kuantitatif yang menggambarkan data berupa angka-angka dan hubungan antar variabel melalui analisis dengan menggunakan alat uji statistik.. Data yang digunakan ini adalah data 
sekunder berasal dari laporan keuangan PT. AKR Corporindo, Tbk pada laman resmi BEI periode 2011-2020, sebanyak delapan data, terdiri dari dua variabel penjelas, satu variabel terikat dan satu variabel perantara. Cara menganalisis data dengan metode statistik dan kuantitatif yang didukung oleh software SPSS. Metode perhitungan yang digunakan adalah analisis regresi, pengujian hipotesis, dan pengujian kekuatan korelasi menggunakan uji R Square, pearson producr moment dan sobel's test.

Tabel 2 Operasionalisasi Variabel Penelitian

\begin{tabular}{|c|c|c|c|c|}
\hline Tabel & Definisi & Indikator & Rumus & Skala \\
\hline $\begin{array}{l}\text { Inetellectual } \\
\text { Capital }\end{array}$ & $\begin{array}{l}\text { Intellectual } \\
\text { capital } \\
\text { merupakan } \\
\text { toak ukur total } \\
\text { saham } \\
\text { berdasarlan } \\
\text { kolektif } \\
\text { pengetahuan, } \\
\text { informasi, } \\
\text { teknologi dan } \\
\text { informasi yang } \\
\text { lainnya. }\end{array}$ & $\begin{array}{l}\text { - Human } \\
\text { Capital } \\
\text { - Structure } \\
\text { Capital } \\
\text { - Capital } \\
\text { Employed }\end{array}$ & $\mathrm{HCE}+\mathrm{SCE}+\mathrm{CEE}$ & Rasio \\
\hline $\begin{array}{l}\text { Growth } \\
\text { Opportunity }\end{array}$ & $\begin{array}{l}\text { Prediksi } \\
\text { kemampuan } \\
\text { perusahaan } \\
\text { untuk dapat } \\
\text { menempati } \\
\text { posisi } \\
\text { ekonomi } \\
\text { secara } \\
\text { keseluruhan } \\
\text { pada industri } \\
\text { sejenis. } \\
\end{array}$ & 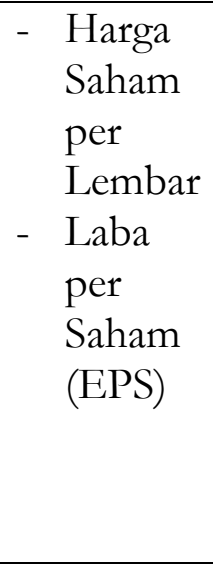 & $=\frac{\text { Harga Saham }}{\text { Laba per Saham }} \times 100 \%$ & Rasio \\
\hline $\begin{array}{l}\text { Financial } \\
\text { Performance }\end{array}$ & $\begin{array}{l}\text { Financial } \\
\text { Performance } \\
\text { adalah analisis } \\
\text { yang dilakukan } \\
\text { untuk melihat } \\
\text { bagaimana } \\
\text { perusahaan } \\
\text { telah } \\
\text { menerapkannya } \\
\text { dengan benar } \\
\text { dan benar } \\
\text { menggunakan } \\
\text { aturan eksekusi } \\
\text { keuangan. }\end{array}$ & $\begin{array}{ll}\text { - } & \text { Laba } \\
\text { Bersih } \\
\text { - } & \text { Total } \\
& \text { Asset }\end{array}$ & $=\frac{\text { Laba Bersih }}{\text { Total Asset }} x 100 \%$ & Rasio \\
\hline
\end{tabular}




\begin{tabular}{|c|c|c|c|c|}
\hline Firm Value & $\begin{array}{l}\text { Pandangan } \\
\text { investor } \\
\text { mengenai } \\
\text { keadaan } \\
\text { perusahaan } \\
\text { perusahaan, } \\
\text { dikaitkan } \\
\text { dengan harga } \\
\text { saham. }\end{array}$ & $\begin{array}{ll}\text { - } & \text { Harga } \\
\text { Saham } \\
\text { - } \text { Book } \\
\text { Value }\end{array}$ & $=\frac{\text { Harga Saham }}{\text { Book Value }} x 100 \%$ & Rasio \\
\hline
\end{tabular}

\section{Hasil dan Pembahasan}

Tulisan ini akan menyajikan temuan penelitian tentang dampak intellectual capital dan growth opportunity terhadap firm value melalui financial performance sebagai variabel mediasi pada perusahaan yang bergerak di bidang pertambangan batu bara yang terdaftar di Bursa Efek Indonesia periode 2011-2020.

\subsection{Uji Asumsi Klasik}

Uji asumsi klasik pada penelitian ini terdiri dari Uji Normalitas, dan Uji Multikolinearitas. Berikut hasil perhitungan yang didapatkan dan interpretasinya:

\section{Uji Normalitas}

Uji normalitas merupakan uji tebakan klasik yang digunakan untuk mengetahui apakah data penelitian berdistribusi normal atau tidak. Tes ini dihitung menggunakan satu sampel Kolmogrov-Smirnov, P-Plot Normal, dan t'Tampilan Histogram. Dibawah ini adalah hasil test pertama.

Tabel 3 Uji Normalitas One Sample Kolmogrov Smirnov Test One-Sample Kolmogorov-Smirnov Test

\begin{tabular}{llr} 
& & Unstandardized Residual \\
\hline N & & 10 \\
\hline Normal Parametersa,b & Mean & .0000000 \\
\cline { 2 - 3 } & Std. Deviation & 3.73806665 \\
\hline Most Extreme Differences & Absolute & .216 \\
\cline { 2 - 3 } & Positive & .199 \\
\cline { 2 - 3 } & Negative & -.216 \\
\hline Test Statistic & & .216 \\
\hline Asymp. Sig. (2-tailed) & & $.200^{\mathrm{c}, \mathrm{d}}$ \\
\hline
\end{tabular}

a. Test distribution is Normal

b. Calculated from data

c. Lilliefors Significance Correction

d. This is a lower bound of the true significance

Mengacu pada tabel yang disajikan diatas, hasil yang diperoleh ialah data intellectual capital, growth opportunity, financial performance dan firm value berdistribusi normal. Hasil ini menandakan bahwa pengujian tahap selanjutnya yaitu pengujian regresi dapat dilakukan. Kemudian untuk memperkuat hasil pengujian di atas, uji normalitas dapat dilihat dari gambar di bawah ini: 


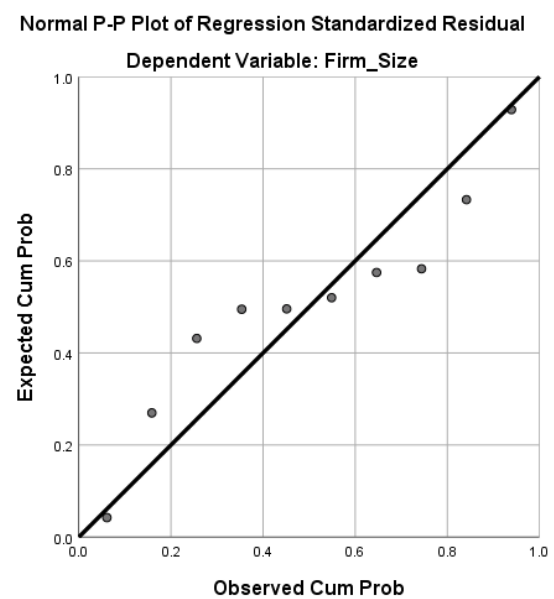

\section{Gambar 1 Uji Normalitas Normal P-Plot}

Sumber: SPSS for windows versi 20.0

Hasil uji normalitas menggunakan Normal P-Plot membuktikan dan memperkuat hasil sebelumnya bahwa intellectual capital, growth opportunity, financial performance dan firm value berdistribusi normal. Hasil tersebut dapat dilihat dari titik yang menyebar pada area garis diagonal.

\section{Uji Multikolinearitas}

Pengujiaan ini dilakukan untuk mengetahui apakah variabel penjelas penelitian saling berhubungan, dalam hal ini intellectual capital, growth opportunity, financial performance dan firm value. Model regresi yang tidak sempurna ialah terdapat hubungan antar variabel bebas, karena akan menimbulkan bias dan hasil diperoleh menjadi tidak maksimal. Berikut hasil uji multikolinearitas yang pengambilan keputusannya menggunakan Tolerance $>0,1$ dan $\mathrm{VIF}<10$.

\section{Tabel 4 Uji Multikolinearitas Descriptive Statistics}

Model Collinearity Statistics

\begin{tabular}{llr|r}
\hline & Tolerance & \multicolumn{2}{c}{ VIF } \\
\hline 1 & Intelectual_Capital & .657 & 1.523 \\
\hline & Growth_Opprtunity & .634 & 1.578 \\
\hline & Financial_Performance & .786 & 1.272 \\
\hline
\end{tabular}

a. Dependen Variabel : Firm Value

Sumber : SPSS for windows versi 26.0

Berdasarkan hasil perhitungan dari SPSS, diperoleh hasil bahwa tidak ada gejala multikolinearitas antara variabel intellectual capital, growth opportunity dan financial performance terhadap firm value. Hasil ini diperoleh untuk variabel intellectual capital nilai VIF sebesar 1,523 dengan nilai tolerance sebesar 0,657. Kemudian untuk growth opportunity dengan nilai VIF sebesar 1,578 dengan nilai tolerance sebesar 0,634. Dan untuk variabel financial performanvce nilai VIF sebesar 1,272 dengan nilai tolerance 0,786 . 


\subsection{STATISTIK DESKRIPTIF}

Statistik deskriptif digunakan untuk menggambarkan data pencarian yang terdiri dari jumlah data pencarian, nilai minimum data pencarian, nilai maksimum, nilai rata-rata dan standar deviasi. Hasil ini diperoleh dengan penghitungan statistik menggunakan SPSS. Berikut hasilnya:

\section{Tabel 5 Statistik Deskriptif}

\section{Descriptive Statistics}

\begin{tabular}{lr|r|r|r|r} 
& N & Minimum & Maximum & \multicolumn{1}{c}{ Mean } & Std. Deviation \\
\hline Intelectual_Capital & 10 & 89.26 & 575.55 & 299.7050 & 144.34714 \\
\hline Growth_Opprtunity & 10 & 5.00 & 27.30 & 19.7000 & 7.66333 \\
\hline Financial_Performance & 10 & 3.40 & 8.20 & 5.9700 & 1.47652 \\
\hline Firm_Size & 10 & 12.59 & 36.34 & 25.5840 & 7.48466 \\
\hline Valid N (listwise) & 10 & & & & \\
\hline
\end{tabular}

Hasil statistik deskriptif menerangkan masing-masing data pada variabel berjumlah 10 data. Tampilan 10 data tersebut dapat dilihat pada grafik di bawah ini:

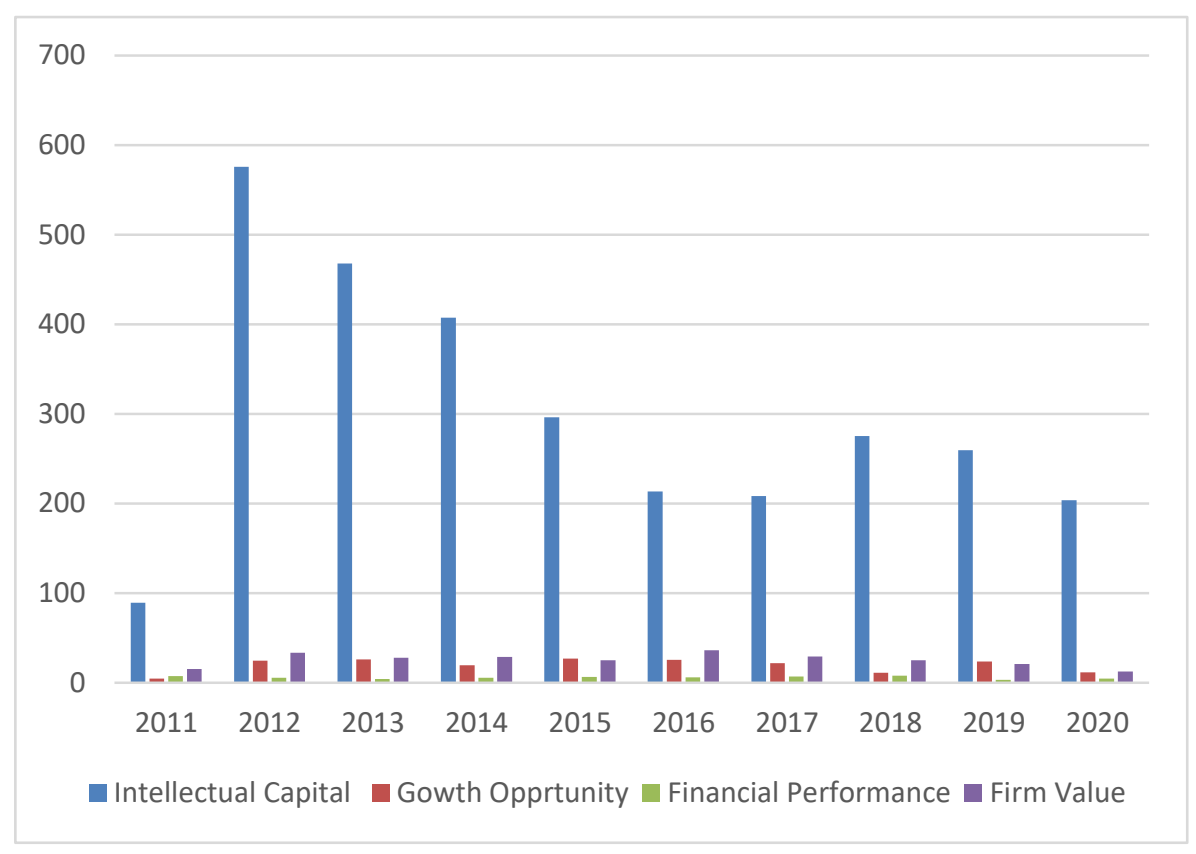

Grafik 1 Perkembangan Data Penelitian

Nilai minimum variabel intellectual capital adalah 89,26 persen, nilai maksimum 575,55 persen, nilai rata-rata 299,7050, dan standar deviasi 144,34174. Variabel growth opportunity minimal 5,00 dan maksimal 27,30\%. Mean adalah 19,70 dan standar deviasi adalah 7,6633. Selain itu, variabel kinerja keuangan minimal 3,40 persen dan maksimal 8,20 persen perusahaan adalah 12,29 persen dan maksimum 36,34 persen. Firm value memiliki mean sebesar 25,5840 dan standar deviasi sebesar 7,4846. 


\subsection{Koefisien Determinasi}

Pengujian koefisien determinasi digunakan untuk mengetahui berapa kontribusi yang variabel independen dan variabel mediasi berikan dalam mempengaruhi variabel dependen. Berikut hasil uji koefisien determinasi

Tabel 6 Hasil Koefisien Determinasi

Model Summary

\begin{tabular}{|c|c|c|c|c|}
\hline Model & $\mathrm{R}$ & R Square & Adjusted R Square & Std. Error of the Estimate \\
\hline 1 & $.724^{\mathrm{a}}$ & .524 & .389 & 5.85262 \\
\hline 1 & $.463^{\mathrm{a}}$ & .214 & -.011 & 1.48434 \\
\hline
\end{tabular}

Mengacu pada tabel di atas, pada model 1 ditemukan bahwa nilai R Square sebesar 0,524 mengandung arti intellectual capital dan growth opportunity memberikan kontribusi sebesar 52,4\% terhadap Firm Value. Untuk model 2, ditemukan bahwa melalui mediasi financial performance, kontribusi intellectual capital, growth opportunity dan financial performance terhadap firm value adalab 0,214 atau 21,4\%.

\subsection{Uji Mediasi}

Uji mediasi dilakukan untuk menguji pengaruh yang diberikan variabel mediasi terhadap variabel dependent. Pada penelitian ini uji mediasi menggunakan uji sobel. Berikut hasil uji sobel:

Tabel 7 Analisis Regresi Pengaruh Intellectual Capital dan Growth Opportunity terhadap Firm Value

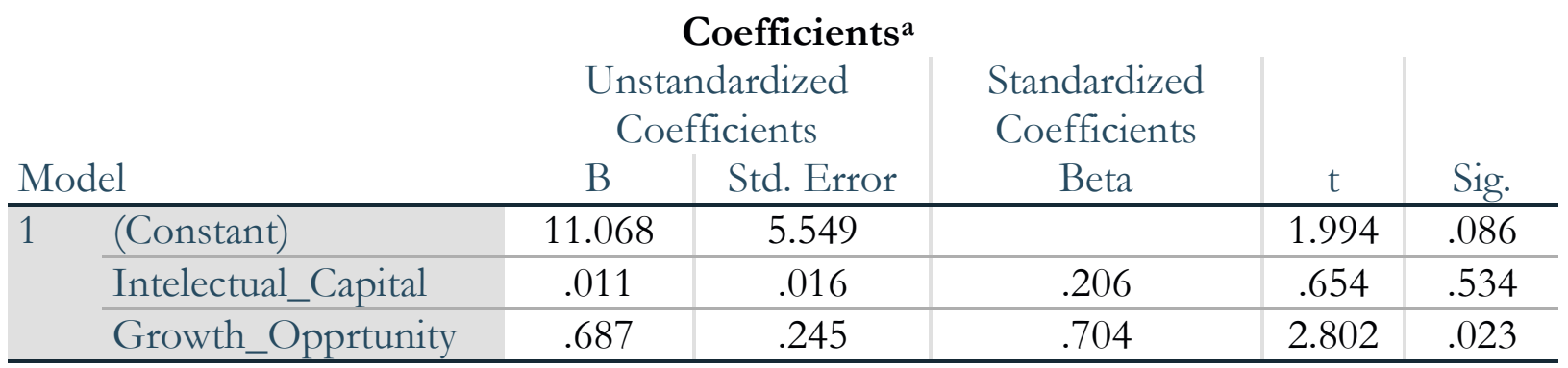

a. Dependent Variabel : Firm Value

Sumber: Hasil output SPSS versi 26

Mengacu pada hasil di atas, nilai koefisien intellectual capital sebesar 0,011 dengan konsekuensi uji $t$ sebesar 0,654 dengan nilai signifikansi 0,543 $>0,05$. Hasil penelitian diatas mengandung arti bahwa variabel independen yaitu intellectual capital tidak memiliki dampak signifikan terhadap firm value. Selanjutnya untuk variabel growth opportunity dengan nilai koefisien sebesar 0,687 dengan konsekuensi uji $t$ sebesar 2,902 dengan signifikansi 
$0,023<0,05$. Hasil pengujian ini mengandung arti bahwa growth opportunity memiliki dampak signifikan terhadap firm value.

\section{Tabel 8 Analisis Regresi Pengaruh Intellectual Capital dan Growth Opportunity terhadap Financial Performance \\ Coefficients $^{\text {a }}$}

Unstandardized Coefficients

\begin{tabular}{|c|c|c|c|c|c|}
\hline Model & $\mathrm{B}$ & Std. Error & Beta & $\mathrm{t}$ & Sig. \\
\hline $\begin{array}{ll}\text { (Constant) } \\
\end{array}$ & 7.790 & 1.407 & & 5.535 & .001 \\
\hline Intelectual_Capital & -.002 & .004 & -.219 & -.541 & .605 \\
\hline Growth_Opprtunity & -.058 & .078 & -.302 & -.746 & .480 \\
\hline
\end{tabular}

a. Dependent Variable: Financial_Performance

b. Predictors: (Constant), Growth_Opprtunity, Intellectual_Capital

Mengacu pada tabel tersebut nilai koefisien intellectual capital sebesar -0,002 dengan hasil uji $t$ sebesar $-0,541$ dengan sig. 0,605 $>0,05$. Mengandung arti bahwa variabel independen intellectual capital tidak mampu memberikan pengaruh dengan signifikan terhadap financial performance. Selanjutnya untuk nilai koefisien growth opportunity sebesar 0,058 dengan hasil uji $t$ dengan nilai $-0,746$ sig. $0,480>0,05$. Mengindikasikan growth opportunity tidak memiliki dampak signifikan terhadap financial performance.

Tabel 9 Analisis Regresi Intellectual Capital, Growth Opportunity dan Financial Performance terhadap Firm Value

Coefficients $^{\mathrm{a}}$

\begin{tabular}{|c|c|c|c|c|c|c|}
\hline \multirow{2}{*}{\multicolumn{2}{|c|}{ Model }} & \multicolumn{2}{|c|}{$\begin{array}{c}\text { Unstandardized } \\
\text { Coefficients }\end{array}$} & \multirow{2}{*}{$\begin{array}{c}\text { Standardized } \\
\text { Coefficients } \\
\text { Beta } \\
\end{array}$} & \multirow[b]{2}{*}{$\mathrm{t}$} & \multirow[b]{2}{*}{ Sig. } \\
\hline & & $\mathrm{B}$ & Std. Error & & & \\
\hline 1 & (Constant) & -10.111 & 10.065 & & -1.005 & .354 \\
\hline & Intelectual_Capital & .017 & .013 & .324 & 1.287 & .246 \\
\hline & Growth_Opprtunity & .733 & .250 & .750 & 2.928 & .026 \\
\hline & Financial_Performance & 2.719 & 1.166 & .536 & 2.332 & .058 \\
\hline
\end{tabular}

a. Dependent Variabel: Firm Value

Sumber: Hasil output SPSS versi 26

Mengacu pada hasil yang disajikan dapat dilihat variabel intellectual capital taraf signifikansi 0,246 > 0,05. Sedangkan variabel financial performance memiliki taraf signifikansi 0,058. Hal ini berarti intellectual capital dipengujian pertama taraf signifikansinya sebesar $(0,534)$ dibandingkan dengan pengujian di persamaan III yang memiliki signifikansi $(0,058)$. Maka dari itu, intellectual capital berpengaruh tidak signifikan terhadap firm value, memiliki hasil yang sama setelah di mediasi oleh financial performance, artinya tidak berpengaruh secara tidak langsung. Dengan demikian hasil dari pengaruh intellectual capital terhadap firm value dengan financial performance sebagai variabel mediasi adalah, bahwa financial performance tidak memberikan efek mediasi secara parsial (partialy mediation).

Untuk variabel growth opportunity memiliki taraf signifikansi 0,026 $<0,05$. Sedangkan dipengujian pertama growth opportunity memiliki nilai signifikansi sebesar $(0,023)$ 
dibandingkan dengan pengujian kedua memiliki taraf signifikansi 0,026. Maka dari itu, pada penelitian variabel growth opportunity berpengaruh signifikan terhadap firm value, selanjutnya memiliki hasil yang sama berpengaruh signifikan terhadap firm value setelah di mediasi oleh financial performance, artinya berpengaruh secara tidak langsung. Dengan demikian hasil dari pengaruh growth opportunity terhadap firm value dengan financial performance sebagai variabel mediasi adalah, bahwa financial performance memberikan efek mediasi secara parsial (partialy mediation).

\section{Signifikansi Hubungan Tidak Langsung}

Hubungan tidak langsung menjadi peran sebagai pengukuran adanya peran mediasi untuk mengetahui seberapa besar pengaruh tidak langsung dan menguji tingkat signifikansinya, dapat mengujinya dengan melakukan uji Sobel.

Tabel 10 Sobel Test Financial Performance dalam memediasi Pengaruh Intellectual Capital terhadap Firm Value

\begin{tabular}{|c|c|c|c|c|c|c|}
\hline & Input & & & t-Statistik & Std. Error & $p$-Value \\
\hline$A$ & -0.002 & $A^{2}$ & \multirow{4}{*}{ Sobel } & \multirow{4}{*}{-0.488} & \multirow{4}{*}{0.011} & \multirow{4}{*}{0.624} \\
\hline$B$ & 2.719 & $B^{2}$ & & & & \\
\hline$S_{a}$ & 0.004 & $S a^{2}$ & & & & \\
\hline$S b$ & 1.166 & $S b^{2}$ & & & & \\
\hline
\end{tabular}

Berdasarkan hasil uji sobel diatas, maka diperoleh nilai besaran (Z) sebesar 0,0488. Kriteria pengujian yang digunakan adalah dapat diterima apabila nilai absolut $Z>$ nilai $Z=-Z$ nilai $-Z$ mutlak $(-1,96=1,96)$. Dengan demikian tingkat signifikansi $5 \%$. Jika dilihat dari gambar diatas, karena nilai $Z(-0,0488)<$ dari nilai $Z$ mutlak $(1,96)$ dengan $p$ value $0,624>0,050$, maka dapat disimpulkan tidak terjadi pengaruh mediasi atau financial performance tidak mampu memediasi pengaruh tidak langsung intellectual capital terhadap firm value.

Tabel 11 Sobel Test Financial Performance dalam memediasi Pengaruh Growth Opportunity terhadap Firm Value

\begin{tabular}{|c|c|c|c|c|c|c|}
\hline & Input & & & t-Statistik & Std. Error & $p$-Value \\
\hline$A$ & -0.058 & $A^{2}$ & \multirow{4}{*}{ Sobel } & \multirow{4}{*}{-0.708} & \multirow{4}{*}{0.222} & \multirow{4}{*}{0.478} \\
\hline$B$ & 2.719 & $B^{2}$ & & & & \\
\hline$S_{a}$ & 0.078 & $S a^{2}$ & & & & \\
\hline$S b$ & 1.166 & $S b^{2}$ & & & & \\
\hline
\end{tabular}

Berdasarkan hasil uji sobel diatas, maka diperoleh nilai besaran (Z) sebesar -0,708. Kriteria pengujian yang digunakan adalah dapat diterima apabila nilai absolut $Z>$ nilai $Z$ $=-Z$ nilai $-Z$ mutlak $(-1,96=1,96)$. Dengan demikian tingkat signifikansi $5 \%$. Jika dilihat dari gambar diatas, karena nilai $Z(-0,708)<$ dari nilai $Z$ mutlak $(1,96)$ dengan $p$-value $0,478>0,050$, maka dapat disimpulkan tidak terjadi pengaruh mediasi atau financial.

\subsection{Pengaruh Intellectual Capital terhadap Firm Value}

Intellectual capital di dalamnya terkandung informasi sekaligus pengetahuan yang menjadi modal dalam kegiatn bisnis dan dapat menciptakan nilai positif (Williams, 2001). 
Secara garis besar, intellectual capital terdiri dari tiga komponen: modal pelanggan, modal manusia, dan modal struktural. VAIC, sebuah metode yang dikembangkan oleh Pulic pada tahun 1998, digunakan untuk mengukur metrik modal intelektual. VAIC terdiri dari value added capital employed (VACA), value added buman capital (VAHU), dan structure capital value added (STVA).

Berdasarkan pengujian hipotesis pertama didaparkan bahwa pengaruh intellectual capital berpengaruh positif yang artinya setiap peningkatan modal intelektual akan menyebabkan peningkatan firm value. Uji hipotesis memperoleh skor aritmatika sebesar 0,011, dan hasil ini berarti bahwa intellectual capital tidak berpengaruh signifikan terhadap firm value. Hal ini tidak mendukung hipotesis bahwa intellectual capital berpengaruh signifikan terhadap firm value.

Hasil ini tidak sesuai dengan teori oemangku kepentingan, yang menurutnya semua tindakan dihasilkan dari penciptaan nilai, yang akan berkontribusi pada penciptaan nilai tambah bagi perusahaan. Karena informasi ini akan menarik investor untuk berinvestasi. Implikasinya investor yang menanamkan modalnya lebih mempertimbangkan nilai perusahaan dari data berupa kuantitatif. Di Indonesia pelaporan intellectual capital belum menjadi sebuah kewajiban serta belum adanya standarisasi sehingga sulit untuk mengkuantifikasikan intellectual capital, sehingga investor masih belum menjadikan intellectual capital sebagai bahan pertimbangan dalam penilaian perkembangan suatu perusahaan sehingga lebih mengandalkan pelaporan atas aset fisik. Hasil penelitian ini sejalan dengan penelitian yang dilakukan oleh Purnomo dan Marcelia (2016) juga sejalan dengan hasil penelitian Ginting dan Nainggolan (2021). Namun berbanding terbalik dengan hasil penelitian yang dilakukan oleh Juwita \& Angela (2016) serta Wijaya dkk (2018) menunjukkan intellectual capital berpengaruh signifikan terhadap firm value.

\subsection{Pengaruh Growth Opportunity terhadap Firm Value}

Growth opportunity peluang untuk pertumbuhan masa depan bagi (Hermuningsih, 2013). Namun, metrik ini memiliki arti yang berbeda untuk setiap perusahan, tergantung pada keputusan pengeluaran yang dibuat oleh CFO (Indasari \& Yadnyana, 2018). Perusahaan dengan growth opportunity yang tinggi cenderung menanamkan modalnya untuk menghindari underinvestment, yaitu proyek investasinya tidak berjalan mulus (Chen et al., 2005). Peningkatan kekayaan pemegang saham dan peningkatan nilai perusahaan akan mempengaruhi peluang pertumbuhan perusahaan masa depan.

Berdasarkan pengujian pengujian hipotesis pertama menunjukkan bahwa pengaruh growth opportunity memiliki pengaruh positif, artinya setiap peningkatan growth opportunity akan menyebabkan peningkatan firm value. Uji hipotesis diperoleh 2,902 temuan ini menunjukkan bahwa firm value sangat dipengaruhi oleh growth opportunity. Hal ini menegaskan hipotesis bahwa peluang growth opportunity memiliki pengaruh yang signifikan terhadap firm value.

Pengujian ini sesuai dengan signaling theory yang menyatakan bahwa tindakan yang diambil oleh perusahaan akan memberikan petunjuk kepada pemegang modal untuk memprediksi prospek perusahaan di masa depan (Brigham \& Houston, 2007). Bantuan tersebut berisi informasi yang memiliki prospek yang baik dibandingkan dengan perusahaan sejenis lainnya. Peluang pertumbuhan menggambarkan seberapa baik perusahaan dapat memposisikan dirinya dalam keseluruhan sistem ekonomi industri serupa (Machfoedz, 1996). Hasil penelitian ini sejalan dengan Indasari dan Yadnyana (2018) dan Hermuningsih (2013). 


\subsection{Pengaruh Intellectual Capital terhadap Financial Performance}

Intellectual capital saat ini disisihkan untuk meningkatkan daya saing perusahaan karena jika dikelola dengan baik akan meningkatkan nilai tambah perusahaan (Halim \& Wijaya, 2020). Menurut teori penawaran berdasarkan sumber daya, perusahaan membutuhkan sumber daya yang berharga, langka, tidak sempurna, dan tidak dapat dipertukarkan untuk memaksimalkan keunggulan yang tidak dimiliki perusahaan lain (Newbert, 2007).

Berdasarkan pengujian pengujian hipotesis pertama diketahui bahwa pengaruh intellectual capital berpengaruh positif, yaitu setiap peningkatan intellectual capital akan menyebabkan peningkatan financial performance. Hasil pengujian hipotesis-t diperoleh 0,541. Hal ini tidak berarti intellectual capital tidak berpengaruh secara signifikan terhadap financial performance.

Implikasinya ialah pengelolaan intellectual capital pada suatu perusahaan masih belum maksimal, kebanyakan perusahaan yang ada di Indonesia masih belum maksimal dalam memanfaatkan jenis modal ini karena perusahaan lebih memilih aset fisik yang lebih cepat menguntungkan bagi perusahaan. Maka dari itu peningkatan atau penurunan intellectual capital tidak menjadi bahan pertimbangan besar bagi perusahaan karean diperlukan penyesuaian yang tepat sehingga belum dapat menjamin akan meningkatkan kinerja perusahaan di masa yang akan datang. Hasil penelitian ini sejalan dengan penelitian yang dilakukan oleh Helmi (2017) \& Halim dan Wijaya (2020). Bertolak belakang dengan hasil penelitian Andriana (2014) dan Wijayani (2017) intellectual capital berpengaruh signifiakn terhadap financial performance

\subsection{Pengaruh Growth Opportunity terhadap Financial Performance}

Perusahaan dengan growth opportunity yang tinggi memiliki nilai investasi yang tinggi terutama pada aktiva tetap yang berumur lebih dari satu tahun, sehingga perusahaan akan mencapai profitabilitas yang tinggi (Said \& Mande, 2020). Untuk dapat memasuki pasar dengan lebih mudah, suatu perusahaan harus memiliki tingkat pertumbuhan yang tinggi, karena perusahaan lebih cenderung memberikan pinjaman kepada perusahaan dengan tingkat pertumbuhan yang tinggi di masa yang akan datang.

Berdasarkan pengujian pengujian hipotesis pertama, ditemukan bahwa pengaruh growth opportunity berpengaruh positif, artinya setiap peningkatan growth opportunity menyebabkan peningkatan financial performance. Hasil pengujian hipotesis $\mathrm{t}$ diperoleh 0,058. Hasil ini tidak berarti bahwa growth opprtunity tidak berpengaruh terhadap financial performance. Hal ini tidak mendukung hipotesis bahwa intellectual capital tidak memiliki pengaruh yang signifikan terhadap financial performance.

Berdasarkan pengujian ini, tidak sejalan dengan packing order theory, yang menyatakan bahwa semakin tinggi tingkat profitabilitas,semakin banyak peluang yang dimiliki perusahaan untuk menggunakan sumber pendanaan internal untuk memenuhi kebutuhan investasi (Oktariana, 2015). Hasil pengujian ini sesuai dengan dengan penelitian Oktariana (2015) dan Said \& Mande (2021) bahwa growth opportunity berpengaruh signifikan terhadap firm value. Namun berbanding terbalik dengan hasil penelitian Harahap (2019) dan Listihayana \& Astusti (2020) menunjukkan growth opprtunity tidak berpengaruh signifikan terhadap firm value. Bertolak belakang dengan hasil penelitian Kusna (2018) bahwa growth opportunity berpengaruh terhadap financial performance. 


\subsection{Pengaruh Intellectual Capital dan Growth Opportunity terhadap Firm Value melalui Financial Performance sebagai variabel mediasi}

Berdasarkan tes sobel, dampak intellectual capital pada firm value melalui financial performance memiliki nilai nilai Z -0,0488 dengan p-value 0,624>0,050, dapat disimpulkan bahwa tidak terdapat efek mediasi atau indikator financial performance tidak mampu memediasi pengaruh tidak langsung dari intellectual capital terhadap firm value. Hasil penelitian ini sesuai dengan penelitian yang dilakukan oleh Jayanti \& Binastuti (2017). Sama halnya dengan hasil uji sobel pengaruh growth opportunity terhadap firm value melalui financial performance memiliki nilai nilai Z -0,708 dengan p-value 0,478 > 0,050 maka dapat disimpulkan tidak terjadi pengaruh mediasi atau financial performance tidak mampu memediasi pengaruh tidak langsung growth opportunity terhadap firm value. Hasil ini menjadi sebuah temuan baru karena belum ada penelitian terdahulu yang melakukan penelitian sejenis.

Keberadaan financial performance tidak menjadi penentu kontribusi intellectual capital dan growth opportunity. Investor lebih mempercayai prospek kinerja perusahaan dari asset yang beruwujud. Jika perusahaan yang memiliki tingkat pertumbuhan yang tinggi, maka dimata investor memiliki kelebihan nilai. Intellectual capital sekarang menjadi bagian yang sangat penting dari perusahaan. Intellectual capital menjadi sangat penting karena merupakan pencarian penggunaan pengetahuan yang efektif dalam bentuk produk jadi, dan bukan informasi (Bontis et al., 2000). Sebagai salah satu strategic asset yang berperan penting pada perusahaan yang bergerak di bidang ekonomi. Saat ini, sudah banyak perusahaan di Indonesia yang berinvestasi dalam pelatihan dan pengembangan karyawan dan meningkatkan hubungan karyawan, serta dalam sistem komputer dan sistem manajemen, karena keduanya dapat menjadi modal fisik dan finansial, tetapi pada kenyataannya, tidak semua perusahaan mengikuti jalan ini, butuh waktu lama. Pengaruhnya dan perspesi investor, yang percaya bahwa aset berwujud memberikan kontribusi yang signifikan bagi perkembangan perusahaan (Zeghal \& Maaloul, 2010).

Evaluasi kinerja perusahaan sangat penting dalam proses perencanaan dan pengendalian dengan menggunakan indikator keuangan, perusahaan dapat menentukan strategi yang digunakan untuk mencapai tujuannya. Karena perusahaan dengan harga saham yang tinggi memberikan nilai tambah bagi perusahaan dan juga membangun kepercayaan pasar tidak hanya pada kinerja perusahaan saat ini, tetapi juga pada prospek masa depan (Ginting \& Nainggolan, 2021)

\section{Kesimpulan}

Berdasarkan hasil penelitian dapat disimpulkan bahwa intellectual capital tidak berpengaruh signifikan terhadap firm value. Pada gilirannya, kemungkinan pertumbuhan secara signifikan mempengaruhi firm value. Namun indikator financial performance tidak memiliki pengaruh signifikan terhadap firm value. Pada pengujian hipotesis kedua intellectual capital dan growth opportrunity tidak memiliki pengaruh signifikan terhadap financial performance. Pada pengujian tidak langsung menerangkan bahwa financial performance tidak mampu memediasi dengan signifikan antara intellectual capital dan growth opportrunity terhadap financial performance. Hal ini mengindikasikan investor masih belum menempatkan intellectual capital sebagai bahan pertimbangan dalam keputusan investasi, karena investor lebih mempercayai informasi dari aset berwujud. Selanjutkan standarisasi mengenai 
intellectual capital di Indonesia masih belum ada, sehingga kebanyakan perusahaan masih belum menjadikan intellectual capital sebagai bahan pertimbangan dalam meningkatkan nilai perushaaan. Keberadaan growth opportunity menjadi sorotan dalam industri manufaktur, jika perusahaan yang memiliki pertumbuhan tinggi otomatis akan meningkatkan nilai perusahaan. Namun variabel financial performance belum mampu memediasi dapat diindikasikan adanya ketimpangan nominal yang sangat jauh dari variabel yang di teliti ini. Apalagi kinerja keuangan yang baik belum tentu menambah nilai bagi sebuah perusahaan.

\section{Referensi}

Andriana, D. (2014). PENGARUH INTELLECTUAL CAPITAL TERHADAP KINERJA PERUSAHAAN (Studi pada Perusahaan Pertambangan dan Manufaktur yang Terdaftar di Bursa Efek). Jurnal Riset Akuntansi Dan Keuangan, 2(1), 251-260.

Astari, A. A. M. R., \& Suryanawa, I. K. (2017). Faktor-Faktor Yang Mempengaruhi Manajemen Laba. E-Jurnal Akuntansi, 20(1), 290-319.

Bontis, N., Keow, W. C. C., \& Richardson, S. (2000). Intellectual capital and business performance in Malaysian industries. Journal of Intellectual Capital, 1(1), 85-100.

Brigham, E. F., \& Houston, J. F. (2007). Essentials of Financial Management : Dasar-dasar Manajemen Keuangan Terjemah oleh Ali Akbar Yulianto. Salemba Empat.

Burhanuddin, \& Yusuf, D. (2019). Pengaruh Struktur Modal Dan Growth Opportunity Terhadap Nilai Perusahaan. Jurnal Sinar Manajemen, 6(1), 1-11.

Chen, M. ., Cheng, J. ., \& Hwang, Y. (2005). An empirical investigation of the relationship between intellectual capital and firm's market value and financial performance. Journal of Intellectual Capital, 6(2), 159-176.

Fahmi, I. (2012). Analisis Kinerja Keuangan. Alfabeta.

Ginting, J. G. A., \& Nainggolan, A. (2021). PENGARUH MODAL INTELEKTUAL TERHADAP NILAI PERUSAHAAN (STUDI EMPIRIS PADA PERUSAHAAN MANUFAKTUR YANG TERDAFTAR DI BURSA EFEK INDONESIA. Jurnal Indonesia Sosial Teknologi, 2(8), 1386-1402.

Halim, Y. R., \& Wijaya, H. (2020). Pengaruh Modal Intelektual Terhadap Kinerja Perusahaan Dengan Manajemen Risiko Perusahaan Sebagai Moderasi. Jurnal Akuntansi Keuangan Dan Bisnis, 13(2), 78-87. https://jurnal.pcr.ac.id/index.php/jakb/article/view/3654

Harahap, R. (2019). Pengaruh Profitabilitas , Growth Opportunity Dan Stuktur Modal Terhadap Nilai Perusahaan Pada Perusahaan Manufaktur Yang Terdaftar Di Bursa Efek Indonesia Tahun 2013-2017. Jurnal Manajemen Tools, 11(1), 175-187.

Herawati, H. (2017). Pengaruh Modal Intelektual Terhadap Kinerja Keuangan Perusahaan. EKOMBIS REVIEW: Jurnal Imiah Ekonomi Dan Bisnis, 5(2), 151-161.

Hermuningsih, S. (2013). Pengaruh Profitabilitas, Growth opportunity, sruktur Modal terhadaP nilai Perusahaan Pada Perusahaan Publik di indonesia. Buletin Ekonomi Moneter Dan Perbankan. https://doi.org/10.1177/027046769801800106

Hong, P. T., Plowman, D., \& Hancock, P. (2007). Intellectual Capital and Financial Returns of Companies. Journal of Intellectual Capital, 8(1), 76-95.

Indasari, A. P., \& Yadnyana, I. K. (2018). Pengaruh Profitabilitas, Growth Opportunity, Likuiditas, dan Struktur Modal Pada Nilai Perusahaan. E-Jurnal Akuntansi, 22(1), 714-746. https://doi.org/10.24843/EJA.2018.v22.i01.p27

Jayanti, L. D., \& Binastuti, S. (2017). PENGARUH INTELLECTUAL CAPITAL TERHADAP NILAI INTERVENING PADA PERUSAHAAN PERBANKAN YANG TERDAFTAR DI BURSA EFEK INDONESIA. Jurnal Ekonomi Bisnis, 
22(3), 187-200.

Juwita, R., \& Angela, A. (2016). Pengaruh Intellectual Capital Terhadap Nilai Perusahaan pada Perusahaan Indeks Kompas 100 di Bursa Efek Indonesia. Jurnal Akuntansi, $8(1), 1-15$.

Listihayana, Y., \& Astuti, S. (2020). Analisis Pengaruh Struktur Modal, Growth Opportunity, dan Risiko Sistematis Terhadap Nilai Perusahaan. Jurnal Ilmiah Mahasiswa Manajemen, Bisnis Dan Akuntansi JIMMBA), 2(1), 64-71. https://doi.org/10.32639/jimmba.v2i1.444

Machfoedz, M. (1996). Akuntansi Manajemen. STIE Widya Wiwaha.

Marcelia, E., \& Purnomo, B. S. (2016). Pengaruh Nilai Tambah Modal Intelektual Dan Pengungkapan Modal Intelektual Terhadap Nilai Perusahaan (Studi Pada Perusahaan Perbankan Yang Terdaftar Di Bursa Efek Indonesia). Jurnal ASET (Akuntansi Riset), 8(1), 41-86. https://doi.org/10.17509/jaset.v8i1.4019

Newbert, S. (2007). Empricical research on the resource - based view of the firm: An assessment and suggestions for future research. Strategic Management Journal, 28, 121146.

Oktariana, F. (2015). PENGARUH GROWTH OPPORTUNITY DAN TAX SHIELD TERHADAP STRUKTUR MODAL DAN KINERJA KEUANGAN PERUSAHAAN (STUDI PADA PERUSAHAAN MANUFAKTUR SEKTOR INDUSTRI BARANG KONSUMSI YANG TERDAFTAR DI BEI PADA PERIODE 2009-2012). JOM FEKON, 2(1), 1-14.

Said, R., \& Mande, H. (2020). Pengaruh Efektivitas Modal Kerja dan Growth Opportunity terhadap Profitabilitas pada Perusahaan Manufaktur Industri Barang Konsumsi yang Listing di Bursa Efek Indonesia. Jurnal Ekonomika, 4(1), 46-57.

Stewart, T. A. (1997). Intellectual Capital, The New Wealth of Organizations. Bantam Doubleday Publishing.

Sunarsih, N. M., \& Rendra, N. P. (2012). Pengaruh Modal Intelektual Terhadap Nilai Perusahaan dengan Kinerja Keuangan sebagai Variabel Intervening pada Perusahaan yang Terdaftar di Bursa Efek Indonesia.". Jurnal Simposium Nasional Akuntansi XV.

Taswan. (2003). Analisis Pengaruh Insider Ownership, Kebijakan Hutang Dan Deviden Terhadap Nilai Perusahaan Serta Faktor-Faktor YangMempengaruhinya. Jurnal Bisnis Dan Ekonomi, 10(2).

Wijaya, R. A., Candana, D. M., Zefriyenni, Z., \& Ridwan, R. (2020). Pengaruh Intellectual Capital Terhadap Nilai Perusahaan Dengan Profitabilitas Sebagai Variabel Intervening (Studi Pada Perusahaan Tambang Yang Terdaftar Di Bursa Efek Indonesia Periode 2014-2018). Jurnal Ilmu Manajemen Terapan, 2(1), 81-95. https://doi.org/10.31933/jimt.v2i1.326

Wijayani, D. R. (2017). PENGARUH INTELLECTUAL CAPITAL TERHADAP KINERJA KEUANGAN PERUSAHAAN PUBLIK DI INDONESIA (Studi Empiris Pada Perusahaan Manufaktur di BEI 2012-2014). Jurnal Riset Akuntansi Dan Bisnis Airlangga, 2(1), 97-116. https://doi.org/10.31093/jraba.v2i1.23

Williams. (2001). Intellectual Capital Performance and Disclosure Practised Related. Journal of Intellectual Capital, 192-203.

Zeghal, D., \& Maaloul. (2010). Analysing Value Added as an Indicator of Intellectual Capital and its Consequences on Company Performance. Journal of Intellectual Capital, 11(1), 39-60. 